\title{
På den internationale anklagebænk
}

Henrik Døcker

\section{Ingen er hævet over loven, men det kræver blod, sved og tårer at håndhæve den}

Carla del Ponte (i samarbejde med Chuck Sudetie): Madame Prosecutor - Confrontations with Humanity's Worst Criminals and the Culture of Impunity, 308 sider, Other Press (New York) 2008.

Carla del Ponte nåede at blive et begreb i den internationale verden i den periode, 1999-2007, hvor hun var chefanklager ved Det Internationale Straffetribunal vdr. Eksjugoslavien. Her er så hendes beretning om disse brydningsfyldte år, hvor hun var konfronteret med 'menneskehedens værste forbrydere og impunitetskulturen'. Det er overmåde vigtigt, at de politisk og militært ansvarlige for folkerettens groveste krænkelser krigsforbrydelser, folkedrab og forbrydelser mod menneskeheden her stilles for retten, samtidig med at man altså kan reflektere over de mange mennesker, der gerne ville friholde dem for straf, dvs. indrømme dem impunitet (straffrihed).
Det er samtidig kreperligt, at den skarpe jurist del Ponte ikke fik ført den tidl. serbiske præsident Slobodan Milosevic til en endelig dom, fordi han døde undervejs, og at den bosnisk-serbiske politiske leder Radovan Karadzic først blev anholdt efter at del Ponte var fratrådt som anklager. Hun måtte nøjes med - i sin nuværende position som Schweiz' ambassadør i Argentina - at erfare hvordan han blev afsløret og siden bragt til Haag. Trods bogens åndelige tyngde må det beklages, hvor meget den kredser om frustrationen over ikke at have fået pågrebet Karadzic og hans håndgange mand, den øverstkommanderende for den bosniskserbiske hær Ratko Mladic.

De mange gentagelser og forudsigelige tekstmængder trætter rent ud sagt læseren. Det kan undre, eftersom del Ponte har fået bistand til at skrive bogen af den erfarne journalist Chuck Sudetic, der 1990-95 rapporterede om Jugoslaviens opløs- 


\section{LITTERATUR}

ning til New York Times, og som selv er forfatter til en almindelig rost bog om grusomhederne i Jugoslavien Blod og Havn (1998). På den anden side forstår man efter læsningen af bogen bedre, hvorfor det har været så vanskeligt at pågribe hovedmændene bag det jugoslaviske blodbad. Solidariteten med ens egen nationale gruppe, det være sig af serbere, bosniakker, kroater eller andet, er ganske overvejende totalt kritikløs. Betydningen af at have internationale straffetribunaler kan derfor ikke overvurderes.

Eftersøgningen af Karadzic og Mladic m.fl. var i lang tid rent symbolsk. Ingen bosniakiske eller serbiske myndigheder, endsige enkeltpersoner, følte sig kaldet hertil trods udsigten til en rimelig økonomisk 'erkendtlighed' for informationer om deres tilholdssted. I denne betændte situation var den schweiziske topjurist del Ponte noget nær den bedst tænkelige på jobbet: Med en ballast som rigsadvokat i sit hjemland Schweiz og anklager i betydningsfulde sager om pengevask og den sicilianske Mafia havde hun bl.a. samarbejdet med den navnkundige italienske undersøgelsesdommer Giovanni Falcone, som i 1992 dræbtes ved et Mafia-attentat.

Hun var stolt af, at Falcone havde kaldt hende 'personificeringen af stædighed', den mand hun på sin side beundrede grænseløst for hans målrettede indsats mod Mafiaen og dens overførsler af 'beskidte penge' til udlandet, herunder Schweiz. Del Ponte deltog i optrevlingen af den italienske Banco Ambrosianos ulovlige overførsler af milliarder af lire til Storbritannien - en bank, som havde tætte forbindelser til Vatikanet. Den flygtede bankdirektør Roberto Calvi, hans mystiske forsvinden og fundet af hans lig, dinglende fra en bro i London, the pizza connection - distributionen af for 1,6 milliarder \$ italiensk indsmuglet heroin via amerikanske pizzeriaer i perioden 1975-84 med påfølgende anholdelse af over en snes skyldige... alt dette og mere til var del Ponte direkte eller indirekte med til at optrevle.

\section{Blodig vej til magt}

Af sikkerhedsgrunde var hun en sjælden gæst i Palermo, men som statsadvokat i den schweiziske kanton Ticino fortsatte hun med Mafiasagerne og hvirvledes ind i den kampagne mod korruption, som den italienske undersøgelsesdommer Antonio di Pietro igangsatte i begyndelsen af 1990'erne. Nu med livvagt hele tiden. Som rigsadvokat fra 1994 satte hun meget ind på at hindre, at Schweiz' banker fortsat tjente som pengevaskeri for international kriminalitet. Hun blev derigennem også en kvalificeret modspiller for Schweiz' store banker. Hen mod slutningen af 1990'erne var billedet imidlertid vendt, sådan opfattede del Ponte det i hvert fald: Bankver- 
denen syntes at have indsat, at det var en fordel ikke hele tiden at blive diskrediteret internationalt ved hver ny afsløring af en større narkohandel eller anden form for organiseret international kriminalitet.

Det er værd at erindre, at FN's Sikkerhedsråd med sin resolution 8227 fra 1993 vedtog at nedsætte et straffetribunal vedr. Eksjugoslavien, allerede mens hvad der er blevet kaldt den internationaliserede borgerkrig i Jugoslavien rasede. Dette hindrede desværre ikke, at den bosnisk-serbiske hær to år senere begik denne del af de moderne Balkan-kriges st $\varnothing r s t e$ forbrydelse: Folkedrabet på ca. 7000 mænd og drenge i Srebrenica i Bosnien-Hercegovina. Carla del Ponte blev ikke alene chefanklager for dette tribunal, men også for det siden nedsatte Straffetribunal vdr. Rwanda. Et vigtigt udgangspunkt for hende var - som hun skriver - at krig ikke udløses af sociale forhold eller kultur, men ved at politiske og militære ledere opildner folkegrupper mod hinanden.

Efter at Kroatien i juni 1995 havde erklæret sig uafhængigt, gik der blot fire måneder før nationalistiske serbere havde erobret en fjerdedel af Kroatien: Den jugoslaviske hær skulle efter alt at dømme sikre, at der ikke blev begået folkedrab på det serbiske mindretal dér. Krigen i Bosnien begyndte i foråret 1992, da det hemmelige politi i Beograd sendte hvad man vel nærmest kunne kalde 'dødspatruljer' af sted - de var sammensat af psykopater, taget fra men- talsygehuse, og decideret forbrydere fra fængsler, begyndende med Bijeljina i det østlige Bosnien.

I Rwanda var det en eksplosiv blanding af fattigdom, overbefolkning, elendige økonomiske muligheder, anarki, jalousi m.v., som gjorde folkedrabet (foranstaltet af hutuer på tutsierne og de moderate hutuer) muligt. Men den udløsende faktor var de militære og politiske ledere, der enten tragtede efter magt eller skulle stabilisere den magt, de havde i forvejen. Den mobilisering, hutuerne foretog, var i virkeligheden begyndt flere årtier tidligere. Hvordan FN's fredsbevarende styrke til Rwanda ligesom FN-styrkerne i Bosnien-Hercegovina ikke fik den fornødne internationalt-politiske opbakning og derfor intet kunne stille op, da først folkedrabet for alvor satte ind, er velkendt.

\section{De små fisk}

Nedsættelsen af de to tribunaler kan med del Pontes ord delvis opfattes som det internationale samfunds bodshandling for den manglende indgriben i tide. Hvorfor Sikkerhedsrådet besluttede, at anklageren for Eksjugoslavien-tribunalet også skulle bestride det tilsvarende job vedr. Rwanda-tribunalet kan forfatteren ikke forklare. Men hun fandt det under alle omstændigheder en god idé. Herved kunne der udvikles en international retspraksis. At det en del år senere besluttedes at skille 


\section{LITTERATUR}

funktionerne ad, sårede givetvis hendes forfængelighed. Arbejdsbyrden med blot ét tribunal var med sikkerhed overvældende! Der skulle $\varnothing v e s$ meget politisk pres ud over det krævende jurist-arbejde med at kæde vidneudsagn om uhyrlighederne sammen med ansvaret hos den og hin politiker eller officer.

Da del Ponte første gang besøgte Serbien hovedstad Beograd i 2001, kunne hun læse en 'hilsen' som graffiti til 'Karla Puttana' - 'Carla luderen', akkurat som den sicilianske Mafia i sin tid havde smædet hende. Men det var dog kort efter oplivende, beretter hun, at møde to modige serbiske kvinder, Natasa Kandic og Sonja Biserko fra den serbiske afdeling af Helsinki-komiteen for Menneskerettigheder. Sidstnævnte oplyste, at et flertal af den serbiske befolkning gerne ville samarbejde med tribunalet.

Del Pontes samarbejde med den serbiske ministerpræsident Zoran Djindic gav hende fortrøstning til at Milosevic, Karadzic og Mladic til syvende og sidst ville blive stillet for hendes tribunal. Men Djindic' forsonlige linje bragte ham i stor fare, og 2003 blev han snigmyrdet af folk fra sikkerhedspolitiet. Afgørende blev, at det nye Rest-Jugoslavien skulle presses politisk, ikke mindst af USA og EU, til at sikre sig de hovedansvarlige for Balkan-krigenes uhyrlige brutalitet. Men i alle del Pontes konfrontationer, det være sig med Rwandas og Serbiens regerin- ger, FN's bureaukrati osv., var en nok så svær én, at hendes hold af kriminelle efterforskere brugte al for megen tid på grave efter lig, udspørge vidner og samle bevismateriale vedrørende lavt rangerende personer, der slet ikke havde det overordnede politiske eller militære ansvar, som FN's Sikkerhedsråd egentlig havde haft for øje med tribunalet.

Del Ponte har utvivlsomt ret, når hun antyder, at verdensoffentligheden ikke rigtig forstod hvor vanskeligt det var at forberede straffesagen mod Milosevic i betragtning af hans taktiske krumspring, besværet med at skaffe vidner med inside-viden, at sikre dem, skaffe udsagn fra politikere og diplomater, hvortil kom obstruktion fra den jugoslaviske ministerpræsident Vojislav Kostunica som Vesten en tid lang nærmest opfattede som sin darling, uanset hans nationalistiske holdning. At få bevisligt 'forbundet' Milosevic og de myriader af kriminelle handlinger, der blev begået vældig langt fra hans kontor i Beograd - folkedrab og krigsforbrydelser i Kroatien, Bosnien-Hercegovina, Kosovo og i Serbien - det var intet mindre end en Herkules-opgave.

Den tidligere jugoslaviske præsident Zoran Lilic skulle vise sig at blive et vigtigt vidne mod Milosevic i Haag: Det var ham, der beskrev Milosevic' dominerende rolle i Jugoslaviens Øverste Forsvarsråd, som kanaliserede betaling af sold til hun- 
dreder af jugoslaviske officerer, incl. Ratko Mladic, som havde direkte forbindelse til Serbiens væbnede styrker i Kroatien og Bosnien-Hercegovina. Milosevic og den bosnisk-serbiske politiske ledelse var del af et 'kriminelt forhavende' med det formål at udrydde dele af den bosniskmuslimske folkegruppe (bosniakkerne), manifesteret i folkedrab i Brcko, Prijedor, Sanski Most, Srebrenica, Bijeljina, Kljuc og Bosanski Novi.

Sikkerhedsrådet forsøgte at standse del Pontes bog, som i sin oprindelige italiensk-sprogede udgave, $L a$ Caccia (Jagten) udkom kort efter at hun havde forladt sit anklagerjob. Det var især begrundet $i$, at hun i bogen havde medtaget en række vedholdende forlydender om kosovo-albaneres grufuldheder over for mellem 100 og 300 kosovo-serbiske fanger. Påstande som ikke har kunnet bære en retslig prøvelse på grund af manglende håndfaste beviser. I det hele taget opfattede del Ponte sit job i overensstemmelse med de højere retfærdigheds- og sandhedsprincipper, som må have foresvævet de oprindelige ophavsmænd til de internationale straffetribunaler: Nemlig at de grove folkeretskrænkelser og den uhyrlige bestialitet, der blev begået i Eksjugoslavien og Rwanda hos begge parter, skulle straffes! Selv om serberne og hutuerne nok stod bag den overvejende del af grusomhederne, så var den anden part ikke lydefri og hævet og strafsanktioner.
Efterforskningen af mulige grusomheder, begået af Kosovos Befrielseshær (KLA) viste sig iflg. Ponte at være noget af hendes anklagemyndigheds mest frustrerende. Kosovo havde i 1999 intet politi, såvel NATO som FN's derværende repræsentation UNMIK påtog sig ugerne at varetage denne myndighedsudøvelse. Det betød igen, at Straffetribunalets anklagemyndighed ikke havde nogen som helst stedlig myndighed at støtte sig til. De relativt få kosovarer, der ønskede at vidne i retsager, skulle have særlig vidnebeskyttelse. Dette igen indebar i nogle tilfælde, at familier i tre generationer burde flyttes af sikkerhedsgrunde. Den kosovo-albanske ministerpræsident Ramush Haradinajs nære forhold til den danske FN-Kosovo-statholder Søren Jessen-Petersen var tydeligvis til stor irritation for del Ponte.

\section{Del Pontes bitre erfaringer}

Den dynamiske schweiziske anklager var fuldstændig på det rene med, at hendes job også indebar evnen til at udøve politisk pres på de magtfulde mænd ikke mindst i USA, som kunne have held til at presse først og fremmest Serbien, men fx også Kroatien, til at samarbejde om udlevering af formodede ledende krigsforbrydere. Men hun var tilbøjelig til at tabe sin kampånd, da USA i 2006 droppede den betingelse, det havde stillet til Serbien for at opnå medlemskab af Partnerskab for Fred, 


\section{LITTERATUR}

nemlig at det samarbejdede med tribunalet.

Men værre var næsten Den Internationale Domstols afgørelse i den sag om Serbiens ansvar for folkedrabet, som Bosnien-Hercegovina havde rejst. Med stemmerne 13-2 konkluderede den, at Serbien som sådan ikke havde begået folkedrab i Bosnien, men at det pådrog sig en vis medskyld, fordi nogle af dets organer og ledende politiske skikkelser ikke aktivt havde medvirket til at forhindre folkedrabet. Denne folkeretskrænkelse udløste ikke erstatning til Bosnien. Men der blev skrevet en form for retshistorie, eftersom det var første gang, at det ved en international domstol konstateredes, at en stat havde krænket folkedrabskonventionen af 1948.

Carla del Ponte slutter af med at konstatere, at der intet forkert var i, at Straffetribunalet vdr. Eksjugoslavien blev oprettet, mens krigen i Bosnien-Hercegovina stadig rasede. Hun mener tværtimod, at netop skabelsen af et sådant internationalt organ kunne tjene til, at færre civile blev ofre for krigen. Retfærdigheden skal med andre ord ikke vente på freden. Selv oplevede hun, at der i hendes embedsperiode, 1999-2007, blev rejst tiltale mod 161 personer. Hun underskrev selv 62 anklageskrifter, mens 91 personer blev taget i forvaring. (Vi hører ikke hvor mange, der blev dømt, men det kan oplyses, at det indtil nu drejer sig om 131 personer, der er dømt til mel- lem to års og livsvarigt fængsel, mens 19 er blevet frifundet. H.D.). Hun kommer ikke nærmere ind på, hvorfor et større antal personer fra Rwanda er blevet dømt for folkedrab, mens kun én har fået denne straf ved Eksjugoslaviens-tribunalet eller i det hele taget problemerne med at bevise folkedrabshensigten. Den største 'fisk' i del Pontes tid var sandsynligvis den kroatiske general Ante Gotovina, der blev pågrebet på De Canariske Øer, røbet gennem en mobiltelefonsamtale. Han havde blod på hænderne fra nedkæmpelsen af det serbiske mindretal i hans land. Han står nu tiltalt for krigsforbrydelser i Haag.

Hun konstaterer helt afslutningsvis, at sådan at være del af en international anklagemyndighed bestemt ikke er en risikofri intellektuel syssel. Det er en hård kamp med mange indkalkulerede risici. Hun er noget desillusioneret, fordi for mange verdenspolitiske ledere, diplomater, efterretningschefer, officerer, bankfolk og forretningsfolk, ja selv FNbureaukrater, er villige til at betragte forbrydere i den særlige vægtklasse af folkedrabsansvarlige og politiske massemordere i det hele taget som en slags partnere, evt. samtalepartnere. Ingen er hævet over loven - i dette tilfælde nutidens folkeret - men det kræver blod, sved og tårer at håndhæve den helt til rettens skranke.

Henrik Døcker er journalist og forfatter. 